\title{
Examining the Knowledge Structure in the Communication Field: Author Cocitation Analysis for the Editorial Board of the Journal of Communication, 2008 and 2011*
}

\author{
Journal of Communication의 편집위원회에 대한 저자동시인용분석을 이용한 \\ 언론학 분야의 지적구조와 사회적 배경 분석: 2008년과 2011년 비교
}

Hyunjung $\operatorname{Kim}\left(\right.$ 김현정 ${ }^{* * *}$

\begin{abstract}
This study examines the social network of scholars in the field of communication by using author cocitation data. A matrix containing the number of cocited documents between pairs of authors is created for social network analysis of scholars who are on the editorial board of Journal of Communication, and the networked map of the scholars is used to visualize the knowledge structure of the field by identifying groups of authors who are more central than others. In addition, the study compares the previous analysis performed in 2008 and the current analysis on the editorial board of the journal, which increased from 146 to 254 scholars in numbers. Author cocitation data was collected using Social Science Citation Index (SSCI) through the Web of Science database, and UCInet was used to create and visualize the author cocitation network and to analyze the correlation between the cocitation network and the factors that may have affected the structure of the cocitation network.
\end{abstract}

\section{초 록}

본 연구는 저자 동시인용 데이터를 이용하여 커뮤니케이션 분야의 학자들간의 네트워크를 연구하였다. 저자 동시인용 분석이란 두 저자가 제 3 의 다른 저자에 의해 동시에 인용되는 경우를 말하는데, 본 연구에서는 International Communication Association의 가장 대표적인 학술지인 Journal of Communication의 편집위원회를 그 대상으 로 하였다. 저자동시인용 데이터는 좌우대칭의 매트릭스에 입력되고, 그 행렬에서 얻어지는 저자들의 위치도 (network map)를 통해 각 저자들의 전문분야들이 위치도 안에서 어떻게 구분되는지, 또한 네트워크 상에서 어떤 저자들이 다른 저자들에 비해 중심적인 지 보여주는 데 이용된다. 기본적인 저자동시인용분석 외에도 두 매트릭스의 연관성을 비교하는 QAP 분석을 통해 어떠한 요인들이 커뮤니케이션 분야의 지식구조에 영향을 미치는 지 조사하였는 데, 저자들의 교육적 배경이나 현재 소속된 기관보다는 각자의 전문분야가 더 많은 영향을 미치는 것으로 나타났다. 저자동시인용분석에 필요한 데이터는 Social Science Citation Index (SSCI) 데이터베이스를 통해 수집되었고, 저자들의 네트워크 지도는 UCInet이라는 프로그램을 이용하여 만들어졌다.

키워드: Author Cocitation Analysis, Social Network Analysis, Journal of Communication, Intellectual Structure, Network Map of Authors 저자동시인용분석, 사회망분석, 언론학, 지적구조, 저자위치도

* 이 논문은 박사학위논문의 축약본이며, 이 논문의 일부는 2008년 AMCIS(Americas Conference on Information Systems)의 Proceedings에 게재된 바 있음.

** Department of Communication, State University of New York at Buffalo(hk48@buffalo.edu) 논문접수일자 : 2012년 5월 18일 논문심사일자 : 2012년 6월 5일 게재확정일자 : 2012년 6월 14일 


\section{Introduction}

The research expands the 2008 study of "social network analysis using author cocitation data" by investigating more current data, including the list of scholars on the current editorial board of Journal of Communication, and adding more attribute data to see if there is any other factors affecting the intellectual structure of authors. The 2008 study examined whether the author cocitation network had a similar structure to the networked map of the ICA divisions that the authors belong to. In particular, the authors are grouped into two main clusters, one with those who are interested in mass communication and the other with those whose interests are not in mass communication. The current university affiliations of the scholars did not show a significant correlation to the author cocitation network. A further investigation on other attributes, such as authors' educational background, is added to see if any of the attributes can be used to predict the structure of the author cocitation network.

\section{Theoretical Background}

\subsection{Sociology of Science and Invisible Colleges}

Whether through conjectures and refutations (Popper 1965) or through a paradigm shift (Kuhn 1962), scientific knowledge goes through changes over time. Some view science as not only a cognitive process, but also a social process (Crane 1972; Freudenthal 1984; Fuchs 1993; Griffith 1989). Crane (1972) explained that "the growth of scientific knowledge is a kind of diffusion process in which ideas are transmitted from person to person" (p. 22). Freudenthal (1984) referred to scientific knowledge as "the contingent product of a social process of construction" (p. 285). From a sociological point of view, Fuchs (1984) emphasized that "scientific change is generally triggered by competition, but that various types of change depend on the social organization and status of scientific groups" (p. 933). This view is related to Popper, who argued that scientific knowledge could gradually get closer to the truth through falsification (Hess 1997, 19-22; Popper 1959, 86-87). Popper's idea of scientific discovery lies in the process of building theories through deductive testing of proposed hypotheses. In the process of selecting a theory, the decision to accept or reject basic statements is important. These could become either universal or singular statements. Unlike conventionalism, which accepts universal statements based on the rule of simplicity, Popper's view accentuates the role of decision making on the result of a test, which is "an agreement about basic statements" (Popper 1959, 109).

However, from the perspectives of history and philosophy, Kuhn criticized Popper's argument on falsification because "scientists often continue to work under a theory or set of theories even when faced with anomalies or refuting instances" (Hess 1997, 23). Kuhn (1962) proposed that scientific revolutions occur when there are changes in a paradigm. 
A paradigm can be defined as "the entire constellation of beliefs, values, techniques, and so on shared by the members of a given community" (Kuhn 1962, 175). Kuhn (1962) explained it as "those non-cumulative developmental episodes in which an older paradigm is replaced in whole or in part by an incompatible new one" (p. 92). The change in a paradigm, or a paradigm shift, involves a group of practitioners in the field because a paradigm is "what the members of a scientific community share, and, conversely, a scientific community consists of men who share a paradigm" (ibid, 176).

In a discussion regarding studies of communication in relation to science, Griffith (1989) recognized the contribution of Merton (1942) to the view of science as a social process, and added that "nearly always Merton is concerned with communication as the basis for analyzing social structure and process" (p. 604). Merton (1996) noticed the influence of social relations and trust among scholars and scientists, and claimed that "all scientific discoveries are in principle multiples, including those that on the surface appear to be singletons" (p. 307). Merton's idea of multiples in scientific discovery affected the creation of citation indexes for scholarly and scientific journals (Garfield 2004). Citation indexes, such as Science Citation Index, can be used to prevent duplications in scientific works by providing bibliographic information on published scholarly documents. In addition, analysis on citation data can be helpful to identify patterns in science, such as most highly cited authors of a subject specialty, or journals that have the greatest impact on a research field. Moreover, analyses on co-cited documents or on co-cited authors can result in meaningful findings.

Sociology of science explains the scientific changes and discoveries in relation to the social structure of scientists. Clusters of highly co-cited documents are considered to have high mutual dependence, because "what happens in one part of the network will have consequences for other parts, and vice versa" (Fuchs 1993, 941). A network of "productive scientists linking separate groups of collaborators within a research area" (Crane 1972, 54) is called invisible colleges and Lievrouw (1989) defined the term as "the informal affiliation of scientists with common interests who were already strongly embedded in other institutions, and who might live some distance from one another" (p. 619). Paisley (1972) listed the defining criteria of an invisible college as "an emergent, informal group, one hundred members or less; interacting leaders; day-to-day communication through informal media such as preprints; a commuting circuit of meetings and collaborative projects" (p. 6). Although the criteria might have been changed since new communication technologies evolved that affect the communication among scholars, the definitions suggested by these scholars still hold some conceptual significance. The Royal Society of London started to use the term "invisible colleges" (Price 1961), and Price $(1963,1966)$ made it more familiar, but the term became widely accepted in the study of scholarly and scientific communication when Crane (1972) elaborated it in her book, Invisible Colleges: Diffusion of Knowledge in Scientific Communities. Although Zuccala (2004) indicated 
that too many definitions have been assigned to the concept and Lievrouw (1989) raised issues regarding the question of process as opposed to structure, the underlying idea of social and informal groups and their role in scientific communication are still recognized by many scholars.

\subsection{Citation Analysis and Cocitation Analysis}

Citation Analysis is one form of the social network studies that use archival data on "who cites whom" (Wasserman and Faust 1994, 51). Citation patterns have been one of the most discussed research topics in information science (Garfield 1965; Cronin 1984). Citations can create networks of various nodes, including journals, individual articles, and authors. When a citation analysis involves pairs of journals, articles, and authors that are cited together, it is called a "cocitation" analysis. Small (1973) defined cocitation as "the frequency with which two items of earlier literature are cited together by the later literature" (p. 265). When a pair of documents is co-cited more frequently than others, they are considered to be more closely related to each other. Information on individual journal citations can be used to examine the impact of journals on the subject field, and a map of co-cited documents can be used to identify subject specialties and sub-specialties. When observed for a period of time, the change in the map of co-cited documents can show the change and knowledge growth in discipline over time (White and McCain 1989, 141-142).
Small and Griffith (1974) proposed a methodology to identify groups of scholars that have affected scientific changes by analyzing clusters of documents that have been frequently cited together. In the process of analyzing clusters of co-cited documents, they realized that the authors of the co-cited documents are worth noticing. Small (1977) later used citation data to introduce methods to identify changes in scientific "specialty". The specialty is "the principal mode of social and cognitive organization in modern science" (p. 139) and clusters of highly co-cited documents are considered to represent the cognitive structure of the field. This subject space is said to be the "current paradigm of the specialty" and the authors of the documents in such clusters are assumed to be the "elite" or "leading scientists of the specialty" (p. 142). Kuhn (1962) mentioned that "a scientific community consists of the practitioners of a scientific specialty" (p. 177). A specialty can be defined as "a group of practitioners with similar training, attending the same conferences, reading and citing the same bodies of literature, and being more likely to talk to each other than to members of different specialties, considerable overlaps and mobility notwithstanding" (Fuchs 1993, 934). Small (2003) investigated the relationship between cocitation analysis of scientific specialties and Kuhn's paradigms by showing "how individual cocitation links could be translated into scientific assertions, and a cluster of such links viewed as an interlocking network of statements" (p. 396). According to Small (2003), cocitation analysis involves collection of highly cited documents of a research field and such procedure appears to be "a 
key step in constructing comprehensive maps of science" (p. 395). Griffith (1989) emphasized the role of the cocitation methodology that it created "a realistic picture of differentiation in science and the speed and extensiveness of change" (p. 612). In other words, the cocitation analysis can be helpful to identify the intellectual structure of a research field as well as changes that occurred in this structure.

Citation analysis on authors can be studied through either intercitation or cocitation occurrences. Intercitation examines a group of authors in a field and counts "how often any member of one group cites any member of the other" (White 2004, 91), while cocitation involves pairs of authors within each group to find out how often the pairs are cited together. Author Cocitation Analysis (ACA) has been used to create a map of co-cited authors to show the intellectual structure and the social structure of the field, using author cocitation counts and similarities among authors (White and Griffith 1981, 163; White and McCain 1989, 146; White 2003, 1250). McCain (1989) examined a set of 58 authors in the field of Drosophila genetics, based on citation data from 1981 through 1986. The map showed clusters of authors who were involved in similar subject topics. In addition, the map showed whether the author's contribution to the field was mostly theoretical, or generally experimental or observational. In summary, mapping co-cited authors is considered to "represent an aggregate consensus that is likely to influence, if not constrain, information use and communication patterns" (p. 679). White and McCain (1998) used author cocitation analysis for "visualizing a discipline", which involved an ex- tensive domain analysis on information science. She later used a method called "tricitation" by using "one cited item (e.g., document, author's name) as a constant in data retrieval and requires that all cocitation counts derive from document referencing any pair of items and the third item" (McCain 2008, 1302). The concept of "tricitation" was first introduced by Small (1974) as "an extension of cocitation in the context of new visualization methods" (McCain 2008, 1302). However, the method was not used widely except Marion's study on citation images of Kurt Lewin (Marion 2002) and McCain's recent study on Conrad Hal Waddington (McCain 2008).

Marion et al. (2003) suggested that social network analysis can be used to explore social structure and complement ACA. White et al. (2003) also suggested using both social network analysis and citation analysis to complement each other's weaknesses. Even though the study involves intercitation analysis, rather than cocitation analysis, it still shows the value of engaging both techniques to investigate the changes in social structure of a research group called Globenet, as well as its influence on the Globenet's intellectual structure. Globenet is a multidisciplinary research institute consisting of members from five different provinces in Canada (Koku et al. 2001). The social network analysis of the research group resulted in three types of ties, including social, sociocognitive, and intellectual ties, where each showed different levels of intercitation likelihood. For example, a collaborator, as one of the variables under sociocognitive ties, showed a significant correlation with both articles and book intercitation. Also, the study suggests 
the possibility that strong intellectual ties might entail social relationships, because those who knew each other before the research group began were more likely to be intercited in articles. Even though the study did not fully answer the question of whether citation reflects social structure, it showed some potential for the use of citation data for analysis of intellectual networks. Their findings suggest "that both prior reputation (here measured by early cocitation) and facilitative social venues (the Globenetters' frequent conferences) can lead individuals to meet, communicate, socialize, and exchange information and knowledge" (White et al. 2003, 125).

In a study on citation networks among communication journals from 1977 to 1985, Rice et al. (1988) identified clusters of interpersonal journals, mass media journals, and residual isolate journals through bibliographic analysis of citation data and a network analysis of citation patterns. Bibliographic analysis of citation data was used to identify the core journals in the field of communication, while network analysis was used to identify citation patterns and clusters of journals through cohesion and position approaches. Cohesion analysis is based on "the degree of linkages between any pair of nodes" and position analysis is based on "the structural equivalence between nodes" (p. 267). Both approaches were used to answer (1) "what areas of communication research exist as shared channels for research results and theoretical debate?", and (2) "which journals perceive the field of communication research in similar ways or are seen as being similar?" (p. 267). In the position approach, cluster analysis and multidimensional scaling were used to identify clusters of core journals based on correlations of both citations received and citations made to other journals. Although Rice et al. acknowledged some weaknesses in the data, including the fact that "there are many other important channels for the flow of scientific information besides journal articles" (p. 278), the research showed solid support for the use of citation analysis in investigating patterns of scientific communication and intellectual structure of a subject area.

A more recent study investigated the usefulness of combining author cocitation analysis and author bibliographic coupling analysis in identifying the intellectual structure of disciplines (Kim and Cho 2010). They collected bibliographic data from articles published in two Korean journals in the field of social welfare from 1999 to 2009 and analyzed cocitation data on 46 authors who were cited more than 18 times. Using Pearson's $r$ in cluster analysis with WARD method, authors are grouped into 8 clusters. They also used multivariate analysis in SPSS to generate a map of authors and compared it to the map generated by author cocitation analysis. The study also investigated whether the authors' age, year in research, their current affiliation and educational background have affected their frequency of being cited. Their research resulted in a map of authors on a graph where $\mathrm{x}$ axis represents a spectrum of qualitative and quantitative research, and y axis represents a spectrum of macro and micro approach. Another study compared the usefulness of author profiling analysis (APA) to author cocitation analysis, using a publication for Architectural Institute of 
Korea (Ryoo and Choi 2011). 46 authors were selected from articles published in 2003 to 2008, and their map indicated that author profiling analysis was more useful in identifying relationships between authors, and distinguishing core and peripheral authors due to the difficulties of obtaining citation indexing data.

\subsection{Social Network Analysis}

Network analysis is "a set of research procedures used to identify structures in social systems based on the relations among the system's components (nodes) rather than the attributes of individual cases" (Barnett 2001, 1640). It can be used to analyze the structure of communication in an organization, and the international monetary, telecommunication and trade networks (Barnett and Danowski 1992; Barnett and Salisbury 1996; Barnett et al. 1999). Wasserman and Faust (1994) defined social network analysis as a method of studying "relationships among social entities" (p. 3). Two of the fundamental concepts are node and link, where a node is the unit of analysis and a link represents the relationship between nodes. A node is also called a vertex in graph theory, an actor in social science, and a point in geometry. A link is also called a loop in network analysis when links are connected to itself, an edge in graph theory, a tie in social science, and a line in geometry. Citation data can be easily converted into network data, since an individual document, author, or journal can be a node and the act of citing each other can be considered as a link. In addition, citation data has most of the properties of networks, such as centrality, density, and tie strength. Centrality refers to "of value in describing differences within and between structures" (Leavitt 1951, 38). The most central position in a pattern is the position closest to all other positions. A quantitative index of the centrality of a position can be found by "(a) summing the shortest distances from each position to every other one and (b) dividing this summation by the total of the shortest distances from the position to every other position" (Leavitt 1951, 47). It is easier to recognize the most central position in some networks but most networks require more clear definition of centrality to determine which one is most central. Freeman (1978/1979) indicated that centrality is "an important structural attribute of social networks" (p. 217) and explained types of centrality based on the structural attributes of a point and of a graph. The explanation of point centrality started with a star-shaped network and these concepts were key attributes in the structure of a network. The center of a star network is a position that "has the maximum possible degree; it falls on the geodesics between the largest possible number of other points and, since it is located at the maximum distance from all other points, it is maximally close to them" (Freeman 1978/1979, 219). In other words, for point centrality, degree centrality refers to a point with relatively high degree, where a degree means "the number of other points to which a given point is adjacent" (p. 218), and betweenness refers to centrality based on "the frequency with which a point falls between pairs of other points on the shortest or geodesic paths connecting them” (p. 221). According 
to Freeman (1978/1979), Bavelas (1948) and Shaw (1954) suggested a person who is "strategically located on the communication paths linking pairs of others" is central, because he or she "can influence the group by withholding or distorting information in transmission" (Freeman 1978/1979, 221). Therefore, it is a useful index of "the potential of a point for control of communication" (p. 224). Another measure of point centrality is closeness, or independence (Leavitt 1951) of a point. A point is considered to be central when it is close to all other points in the graph in this sense. The use of these three types of point centrality depends on the context. In conclusion, "concern with communication activity suggests a degree-based measure. Interest in control of communication requires a measure based upon betweenness. And concern with either independence or efficiency leads to the choice of a measure based upon closeness" (Freeman 1978/1979, 226). Centrality or centralization of a graph involves the compactness of a graph, where "a graph is compact to the degree that the distances between pairs of its points are short" (ibid, 227). Common features of all indexes of graph centralization include "(a) they should index the degree to which the centrality of the point central point exceeds the centrality of all other points, and (b) they should each be expressed as a ratio that excess to its maximum possible value for a graph containing the observed number of points" (ibid, 227). These traditional types of centrality measures are useful but some concerns that they are not considering the flow of network traffic (Borgatti 2005).

Citation analysis of journals in a subject specialty can identify core journals of the field, by examining citation frequencies of each journal. Highly cited journals can be considered as core journals, which have more influence on scientists than other journals in the periphery. Core journals in citation analysis are central nodes in network analysis. Moreover, the number of citations can be used as the tie strength, where highly cited documents, journals, or authors are considered to have higher level of tie strength. The strength of a tie is defined as "a (probably linear) combination of the amount of time, the emotional intensity, the intimacy (mutual confiding), and the reciprocal services which characterizes the tie" (Granovetter 1973, 1361). The concept of tie strength can be also applied to citation analysis. In a study of citation networks of communication journals, Rice et al. (1988) denoted that journals with "weak links" to other interpersonal journals "may play a valuable role in expanding the diversity of scientific information within the interpersonal clique" (pp. 271-272). For co-cited authors, the strength of ties may be useful to identify the most frequently cited pairs of authors as well as those who are not cited as often as strong ties but useful to provide diverse knowledge to the clusters or groups to which they belong.

\subsection{Research Questions}

- RQ1: Does the network analysis of authors identify groups?

The proposed study will examine whether the network analysis of authors represents the knowledge structure of the authors (McCain 1986). It may be 
a sparse network, but the map of authors is expected to show who are often cited together. Each group or cluster of authors may be associated with a particular specialty of communication research, for example, mass communication or interpersonal communication.

- RQ2: Does the degree of centrality of authors vary within groups?

Within each cluster of authors, the proposed study is expected to identify those who are more central than others. White and McCain $(1989,124)$ used the concept of "core" and "scatter" to describe productivity of journals or authors, and Barnett and Park (2005) used the concept of "the core, the periphery, and the semi-periphery" (p. 1112) for similar reasons. The analysis of centrality may be helpful to identify those who can act as a weak tie that provides diverse information to the group they belong to (Granovetter 1973; Rice et al. 1988).

- RQ3: Does the author cocitation network show any change over time?

Since the proposed study will have the new networked map of authors who are on the editorial board of Journal of Communication in 2011, it must be interesting to see if there's any change over time in the structure of the network. Some members stayed, some left, and some new members were added to the board. Even though the new cocitation network is composed of different group of members from the previous study, it is assumed to have the same or similar structure due to the collective characteristics of knowledge (Brown and Duguid 1998).

\section{Data and Method}

The study uses a group of scholars on the editorial board of Journal of Communication as the target of author cocitation analysis. Editorial board members of journals have been used for studies of social network analysis in various subject fields (Baccini and Barabesi 2011; Burgess and Shaw 2010; Malin and Carley 2007). Journal of Communication is one of the journals published by the International Communication Association (ICA), an international scholarly organization "with more than 3,500 members in 65 countries" (http://www.icahdq.org/about_ica/ind ex.asp). Among 5 journals of the ICA, Journal of Communication is selected because it claims to cover all areas of communication research. Therefore, it is assumed that the editorial board of Journal of Communication must have included scholars in a broad range of communication research. Park and Leydesdorff (2009) also used Journal of Communication as the seed journal for their research in knowledge linkage structures in communication studies. In addition, the size of the editorial board expanded from 146 scholars in 2008 to 254 scholars in 2011.

First, names of the scholars on the Journal of Communication editorial board were collected and searched for their indexed names in the Web of Science database. The Web of Science database contains Science Citation Index Expanded (SCI-EXPANDED), Social Science Citation Index (SSCI), and Arts \& Humanities Citation Index (A\&HCI), and this study uses Social Science Citation Index (SSCI) for data collection. Each name in the list is searched for its 
indexed counterpart in the database to enhance the accuracy. For example, "Scott L. Althaus" is indexed as "Althaus SL" in SSCI. The indexed names are searched using the author finder or the basic search function. The author finder shows works of the searched name, and sometimes a further search is required to verify whether the indexed name matches the scholar in question. Refining either the web of science categories or the subject areas to communication helps to narrow down the list of possible indexed names of the author. However, sometimes communication doesn't appear in the list of the web of science categories or the subject areas because the list only shows the first 100 categories or subject areas. In this case, the basic search for the author is performed to see if there is any publication under the author's name. If none of these searches results in the exact match, the author is excluded from the data, even if there is the same name but the publication is not in the field of communication. Common names, such as John Smith, may yield many search results and require further refinements which makes the search for the indexed names more difficult. Also, foreign scholars, such as Yi-Hui Huang, are not easy to find the indexed names because there are possible spelling variations.

After finding the indexed names of each author, cited references under the author's name is searched using the "cited reference search" function in SSCI. Cited reference search is performed in two steps. In Step 1, a search for an author's name results in a list of cited references. For example, a search for "Althaus SL" as a cited author resulted in 59 references in 2011. Using "Select All" and applying some restrictions, i.e., language as English and type of documents as articles, the search is finished and the next step shows a list of citing articles. For example, the search for citing articles of "Althaus SL" resulted in 347 English articles. It means there are 347 articles that cited 59 works of "Althaus SL".

Each search produces a numbered set in the search results section. For example, the results for "Althaus SL" are set number 1, and the results for "Andersen PA" are set number 2. The author cocitation counts can be obtained by combining two sets of cited references searches, using the "AND" operator in the search results page. The "advanced search" offers a text box to put in a text-based query, which is faster and more convenient than clicking the checkbox for each set and the "AND" operator radio button in the search results page. The combining searches for Scott $\mathrm{L}$. Althaus and Peter Andersen resulted in 1, which means there is one article that cites works of both Scott L. Althaus and Peter Andersen until 2011. Even if the search for a particular author includes works that are not actually written by the intended author, the process of combining two sets of searches reduces the possibility of such errors.

With the cocitation counts for each pair of authors, a matrix of 146 rows and 146 columns was created for the 2008 study. The cocitation matrix of the 2011 study consists of 246 rows and 246 columns after excluding names that do not have the indexed counterpart. The matrix is non-directional and symmetric since both cell $a_{i, j}$ and cell $a_{j, i}$ represent the number of works that cite author $i$ and author $j$. The numbers of self-citation, such as $a_{i, i}$, are not 
counted because they are not necessary for the analysis. The matrix was used to create a networked map of authors using UCInet. In particular, a program called NetDraw was used to transform the UCInet data into the networked map. The original matrix contains cocitation counts in half of the matrix as a triangular shape because it is symmetrical, and UCInet symmetrizes the matrix and fills in self-citation blanks with 0 s for analysis.

In addition to the cocitation matrix, a number of other matrices were created to see if any of the attributes might have affected the cocitation structure. A matrix of each author's current university was created with 146 rows of authors and 73 columns of academic institutions in 2008. In 2011, there are 101 current affiliated institutions for 246 scholars. Another matrix of ICA divisions was used to see if each author's interest relates to the structure of their cocitation pattern. The latter matrix consists of 146 rows for authors in 2008 and 246 rows for 2011 analysis, 22 columns for 18 ICA divisions, 3 interest groups, and a Communication Institute for Online Scholarship (CIOS) membership (Lee 2008). A matrix of each author's educational background, i.e., where they obtained their Ph.D., was added in 2011. The educational background matrix consists of 246 rows for authors and 60 columns for universities.

The QAP (Quadratic Assignment Procedure) analysis in UCInet (Borgatti, Everett, and Freeman 2002) was used to identify correlations between the cocitation matrix and additional matrices created for attributes such as the author's current academic institutions, educational background, and ICA divisions they be- long to. The QAP correlation procedure requires the equally sized square matrices "to test the association between networks" (UCInet 6 for Windows Help; Borgatti, Everett, and Freeman 2002). Consequently, the attribute data matrices with non-equal number of rows and columns are converted into square matrices consisting of the same number of rows and columns for authors. Then the cocitation matrix and one of the attribute matrices are compared with the QAP correlation procedure. The 2008 study used the current university affiliation network and the ICA division network for comparison with the author cocitation network, and it turns out that the ICA division network has more similar structure to the author cocitation network. Moreover, the correlation between the author cocitation network and the ICA division network shows that authors are grouped into those who are interested in mass communication and those who are not.

\section{Results and Analysis}

\subsection{QAP Analysis}

The 2008 study shows the QAP correlation between the author cocitation network and the ICA

〈Table 1〉 QAP Matrix Correlation - 2008

\begin{tabular}{l|c|c}
\hline \hline & $\begin{array}{c}\text { Pearson } \\
\text { Correlation Value }\end{array}$ & Significance \\
\hline Current Affiliations & 0.045 & 0.008 \\
\hline ICA Divisions & 0.161 & 0.000 \\
\hline
\end{tabular}


divisions is slightly higher $(r=0.161, p=0.000)$ than the correlation between the author cocitation network and their current university affiliations. The cocitation network of scholars on the Journal of Communication editorial board has similar structure to their membership to ICA divisions, rather than to their current university affiliation. Kim, Kim, and Kim (2008) also used QAP analysis to figure out whether similarities in authors' affiliations or educational background affected the likelihood of being cited together. Their findings show similarities in authors' subject specialties increase the chance of cocitation (p. 137). Figure 1 displays the networked map of selected authors, who are considered to be more central than others. The threshold for this network was set at 26 , which means these are tied with more than 26 cocitation counts. Nodes in blue circles are those who belong to the mass communication division, and the networked map shows the authors are mainly grouped into those who belong to the mass communication division and those who do not.

This study investigated whether the patterns of author co-citation can describe the structure of the field of communication. The network analysis shows two main clusters of authors, based on their membership of the ICA divisions. In particular, members of the mass communication division form a larger cluster, which reflects the current structure of the editorial board of Journal of Communication. The result supports findings from previous studies regarding the structure of the communication discipline (Barnett and Danowski 1992; Doerfel and Barnett 1999) in parts, as Barnett and Danowski (1992) found more groupings than the dichotomizing grouping of

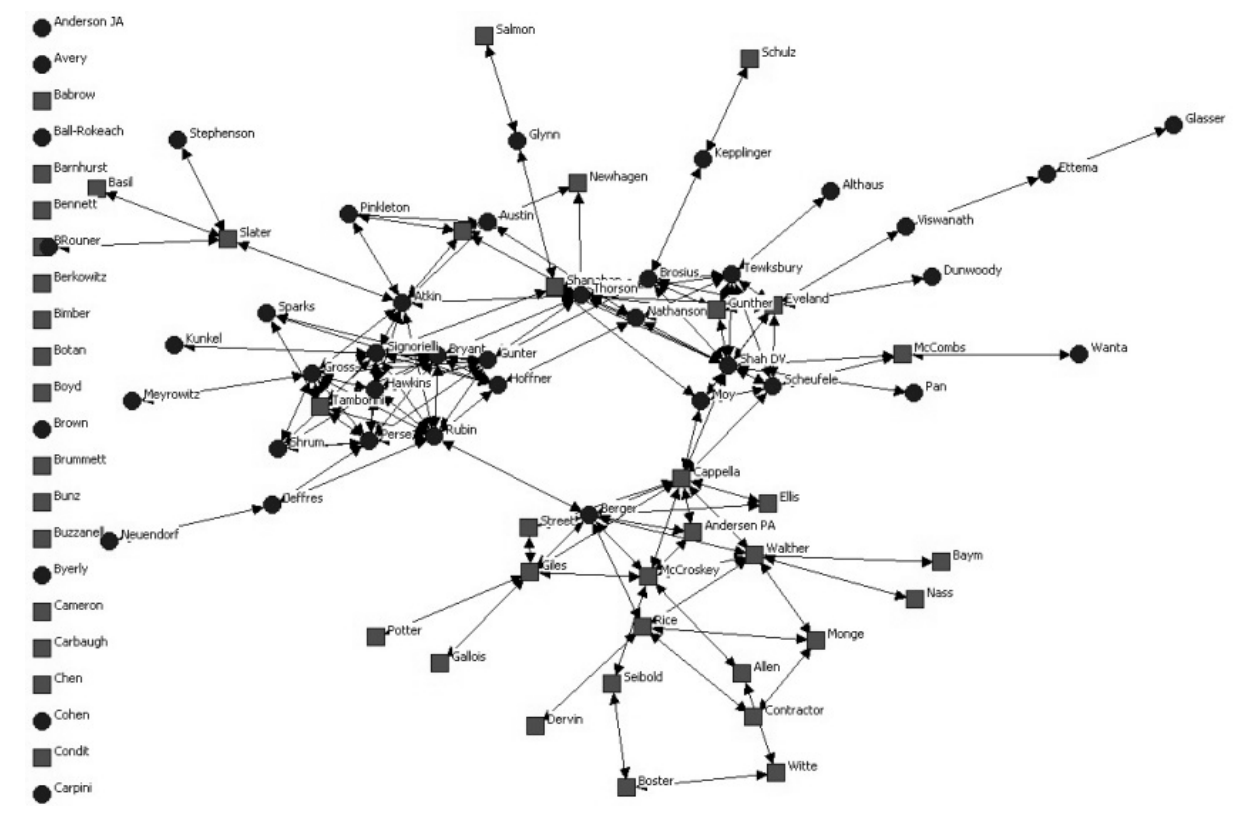

〈Figure 1〉 Networked Map of Authors - 2008 
〈Table 2〉 QAP Matrix of Correlation - 2011

\begin{tabular}{l|c|c}
\hline \hline & $\begin{array}{c}\text { Pearson } \\
\text { Correlation } \\
\text { Value }\end{array}$ & Significance \\
\hline ICA Divisions & 0.092 & 0.000 \\
\hline Current Affiliations & 0.067 & 0.000 \\
\hline Education & 0.044 & 0.001 \\
\hline
\end{tabular}

mass media and interpersonal clusters.

Although the Pearson's correlation value decreased from 0.161 to 0.092 , the ICA division is still a stronger factor that may have affected the structure of the author cocitation network. The difference is the current university affiliations $(r=0.067)$ also became significant $(p=0.000)$.

Obviously, the networked map of authors in 2011 needs a new threshold. When it displays ties with higher than 26 counts as in 2008 study, the map just looks like a big lump of nodes. After more thresh- old were tested, it turns out that the threshold for an optimal networked map of authors turns out to be 46 for the 2011 analysis, almost twice the threshold for the 2008 study. (Figure 2, 3).

Figure 4 shows the networked map of authors at 46 as the threshold. Now the map shows at least two main clusters, and the two clusters are clearer with membership to the mass communication among the ICA divisions. Again, among 22 divisions of the ICA, the membership to the mass communication acts as a criterion to distinguish groups in the author cocitation network.

Regarding other attributes of the authors, there were 73 institutions included in the 2008 analysis of the author's current affiliations, and it increased to 101 institutions for 2011 study's 246 scholars. Also, the 2011 analysis added a matrix of author's educational background as an attribute data, which includes

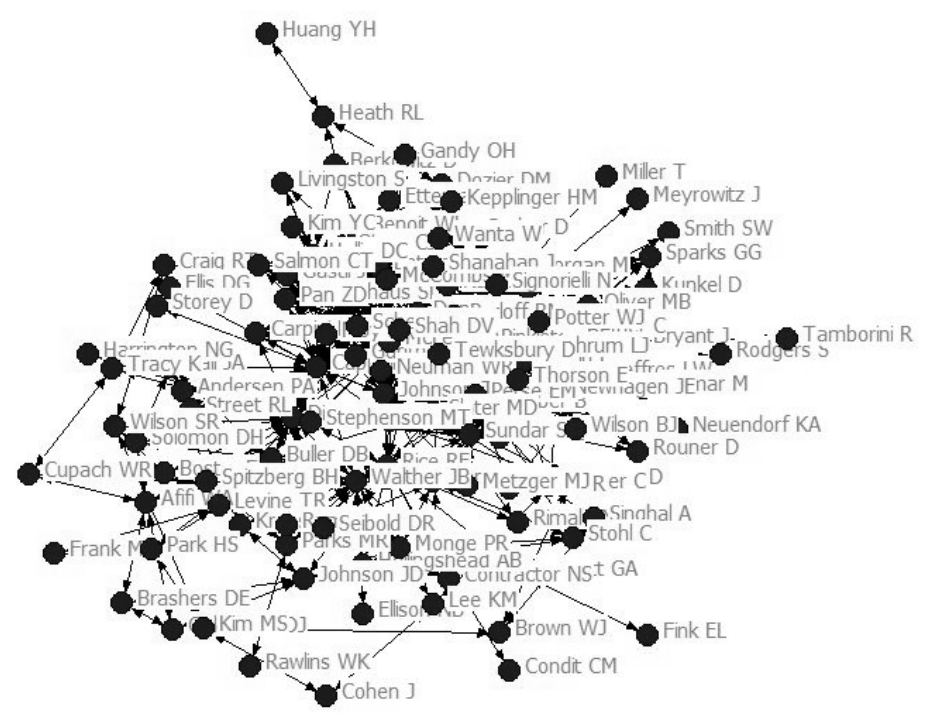

〈Figure 2〉 Networked Map of Authors - 2011

(Threshold at 26) 


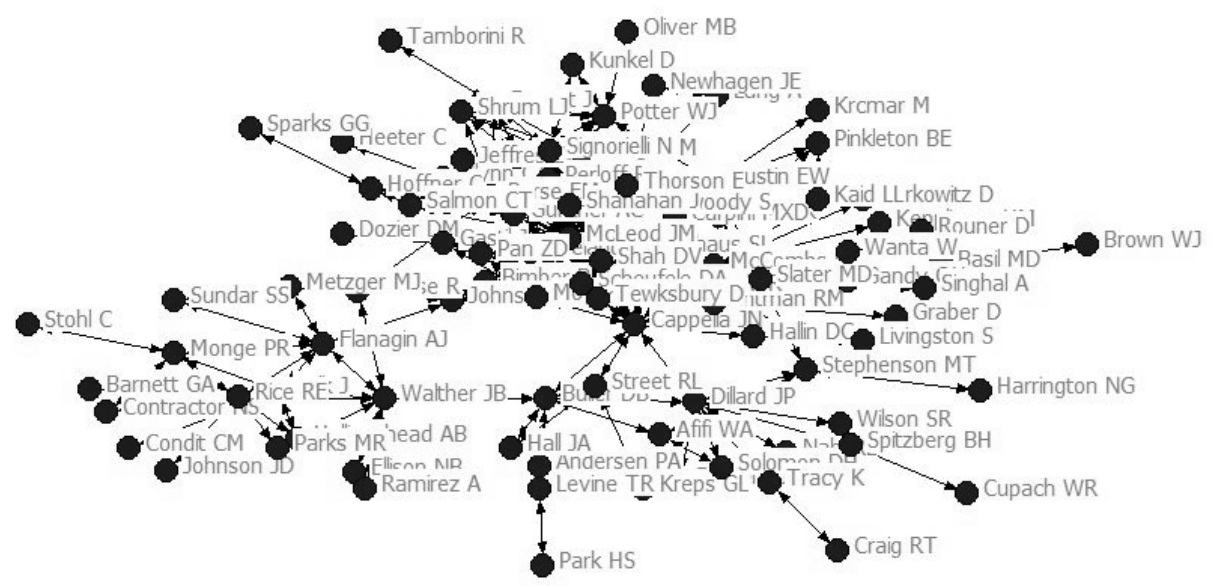

〈Figure 3〉 Networked Map of Authors - 2011

(Threshold at 46)

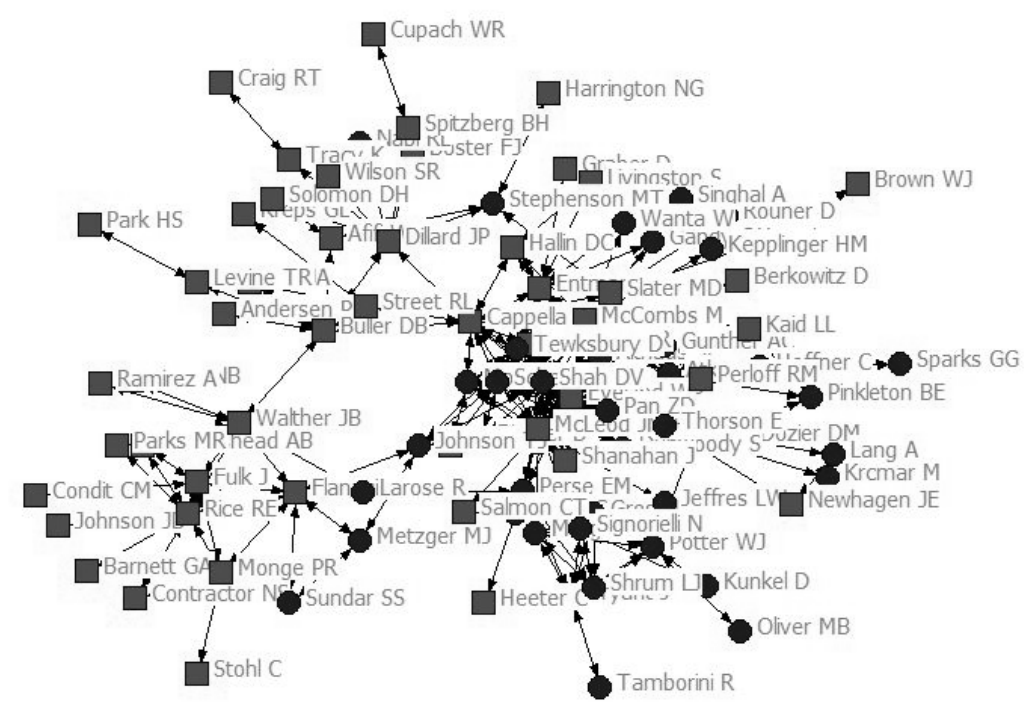

〈Figure 4〉 Networked Map of Authors - 2011

(Threshold at 46, Red Square for Mass Communication)

60 universities. Table 3 and 4 show lists of universities to which higher number of scholars belong.

As the tables show, scholars are rather widely dispersed regarding the current affiliations, while their educational backgrounds are slightly focused on several schools. Among 246 scholars, about 13.5\% are graduates from the University of Southern California. Combining Michigan State University and University of Wisconsin graduates constitute about $19.5 \%$ of the editorial board. 
〈Table 3〉Current University Affiliations - 2011

\begin{tabular}{l|c}
\hline \hline \multicolumn{1}{c|}{ University } & Number of Affiliated Scholars \\
\hline Michigan State University & 14 \\
\hline UC Santa Barbara & 13 \\
\hline University of Southern California & 13 \\
\hline University of Wisconsin & 10 \\
\hline Ohio State University & 9 \\
\hline University of Texas1) (Austin, El Paso, San Antonio) & 7 \\
\hline University of Illinois at Urbana Champaign & 7 \\
\hline
\end{tabular}

〈Table 4〉 Educational Background - 2011

\begin{tabular}{l|c}
\hline \multicolumn{1}{c|}{ University } & Number of Scholars \\
\hline University of Southern California & 33 \\
\hline Michigan State University & 24 \\
\hline University of Wisconsin & 24 \\
\hline Stanford University & 14 \\
\hline University of Minnesota & 10 \\
\hline University of Pennsylvania & 9 \\
\hline University of Illinois at Urbana Champaign & 7 \\
\hline Indiana University & 7 \\
\hline
\end{tabular}

Figure 5 shows the map of authors with focus on those who are affiliated with the Michigan State University (MSU) in blue square. Even though the MSU is the university with which most authors are currently affiliated, the map shows those who are affiliated with the MSU are rather in the periphery of the network. Maybe it is because the current affiliation is not as strong as the ICA division membership in regard to affecting the structure of the author cocitation network.

In regard to the author's educational background, the group of those who received their doctoral degree from the University of Wisconsin shows some level of cohesion compared to other universities, although the map only contains about half of those who graduated from the University of Wisconsin. (Figure 6).

Examining these networked maps of authors indicates the structure of the author cocitation network has not been changed greatly since 2008 , even though new members have been added. It appears that more members are located in foreign countries outside the U.S. than in 2008, but most of the members are affiliated with universities within the U.S. and even if they are located in foreign countries, such as Israel, Germany, Japan and Hong Kong, they are more likely to have obtained their doctoral degree

1) Numbers for the University of Texas include University of Texas at Austin, at El Paso, and at San Antonio for the purpose of easier analysis on the network. 


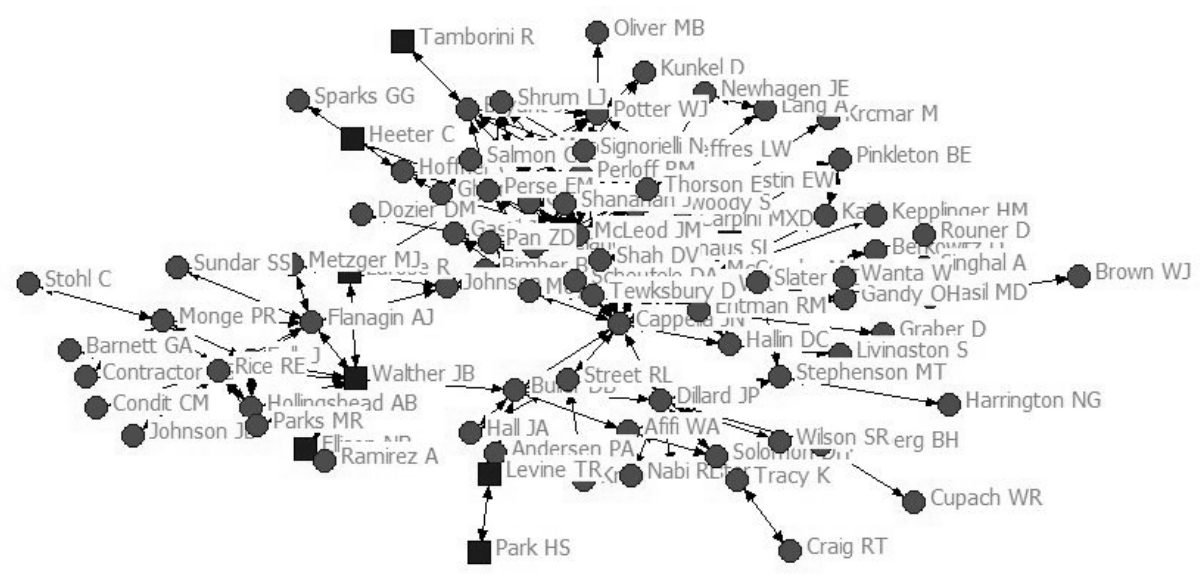

〈Figure 5〉 Networked Map of Authors - 2011

(Michigan State University Affiliation in blue square)

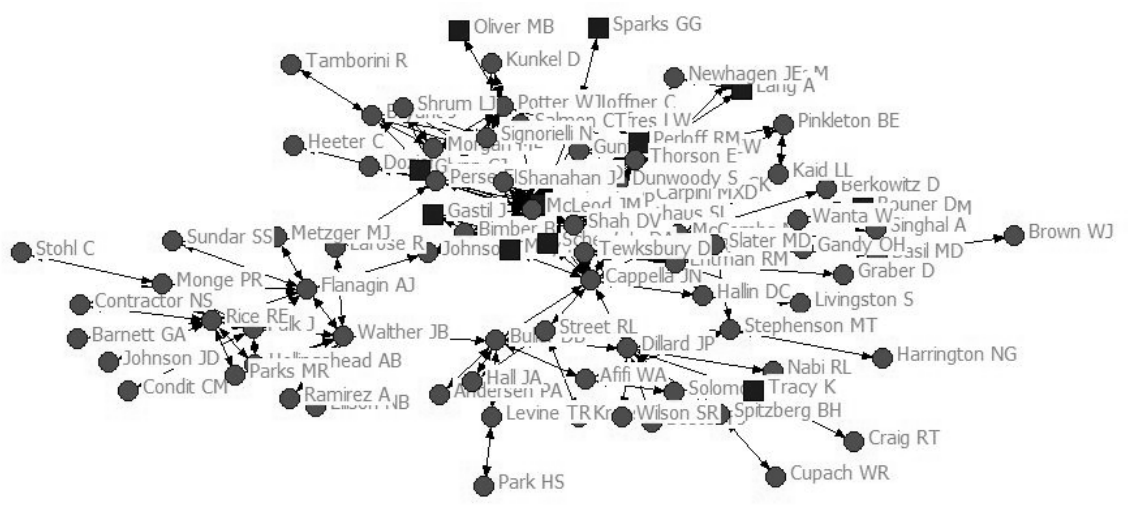

〈Figure 6〉 Networked Map of Authors - 2011

(University of Wisconsin in blue square)

from the U.S. universities.

Figure 7 shows the networked map of authors at the threshold of 46 , and combination of current affiliation and educational background. The nodes in blue circle indicate those who received their doctoral degree from Michigan State University (MSU), and the nodes in blue square are those who are currently affiliated with MSU. It shows a clearer picture of how education and current affiliation are associated with the structure of cocitation network, rather than their respective correlation. Regardless of the time period when they were associated with the university, either through education or through affiliation, the current and previous affiliation with the university matter in the structure of a discipline. 


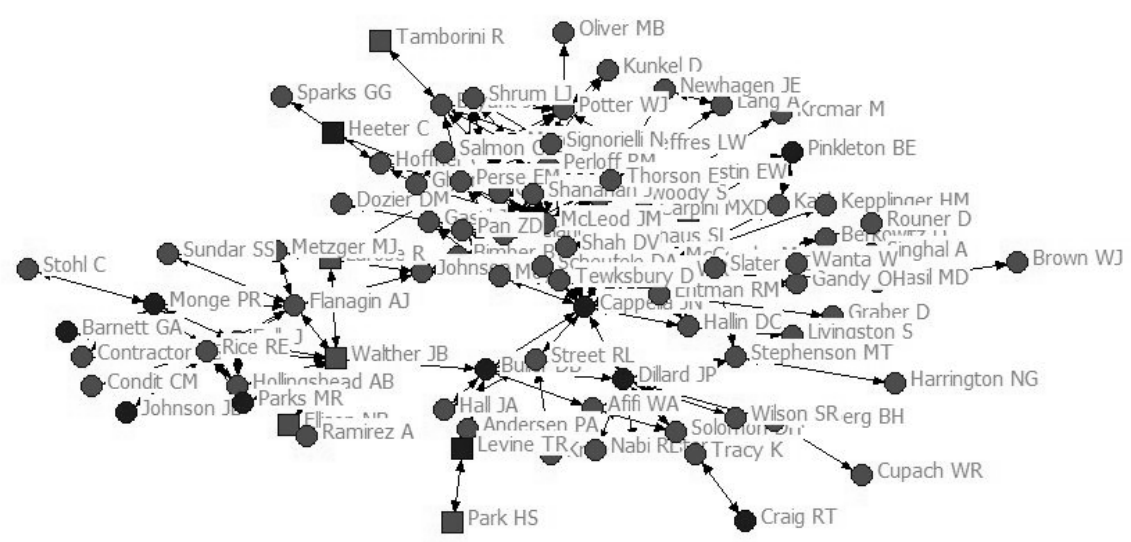

〈Figure 7〉 Networked Map of Authors - 2011

(Current \& Education Combined)

\subsection{Centrality}

The second research question of this research is to see if the degree of centrality of authors varies within groups. First, the mean of degree centrality decreased from 39.093 to 33.818 over the past three years. Other centrality measures also decreased, except the closeness centrality which increased from 38.462 to 60.569 . (Table 5, 6).

Table 7 shows a list of top 30 degree centrality in 2008 and 2011. Notice the top degree centrality in 2011 does not reach the $15^{\text {th }}$ degree centrality in 2008. However, scholars with higher degree centrality in 2008 tend to stay in the higher rankings of the degree centrality in 2011. Among the top 10 in 2008, "Rice RE" became the highest degree centrality in 2011 , and others mostly stayed in the top 30 except "Gross L" who dropped to the $55^{\text {th }}$, and "Rubin AM", "Hawkins RP", and "McCroskey JC", who are not on the editorial board any longer.

〈Table 5〉 Descriptive Statistics for Centrality 2011

\begin{tabular}{c|c|c|c|c}
\hline \hline & Degree & Closeness & Betweenness & Eigenvector \\
\hline Mean & 33.818 & 60.569 & 0.274 & 7.901 \\
\hline Std Dev & 16.241 & 6.212 & 0.203 & 4.344 \\
\hline Sum & 8319.184 & 14899.94 & 67.421 & 1943.723 \\
\hline
\end{tabular}

〈Table 6〉 Descriptive Statistics for Centrality 2008

\begin{tabular}{c|c|c|c|c}
\hline \hline & Degree & Closeness & Betweenness & Eigenvector \\
\hline Mean & 39.093 & 38.462 & 0.427 & 10.422 \\
\hline Std Dev & 20.047 & 3.248 & 0.469 & 5.325 \\
\hline Sum & 5707.586 & 5576.992 & 62.356 & 1521.668 \\
\hline
\end{tabular}


〈Table 7〉 Centrality Rankings - 2008 and 2011

\begin{tabular}{|c|c|c|c|c|}
\hline & \multicolumn{2}{|c|}{2011 Degree Centrality } & \multicolumn{2}{|c|}{2008 Degree Centrality } \\
\hline 1 & Rice RE & 66.122 & Perse EM & 76.552 \\
\hline 2 & Cappella JN & 64.082 & Rice RE & 75.172 \\
\hline 3 & Buller DB & 63.265 & Cappella JN & 74.483 \\
\hline 4 & Dillard JP & 61.224 & Rubin AM & 73.103 \\
\hline 5 & Brown WJ & 59.592 & Gross L & 71.724 \\
\hline 6 & Bryant J & 59.592 & Allen M & 69.655 \\
\hline 7 & Atkin CK & 59.184 & Thorson E & 69.655 \\
\hline 8 & Slater MD & 58.776 & Shah DV & 68.966 \\
\hline 9 & Tewksbury D & 58.776 & Hawkins RP & 68.276 \\
\hline 10 & Thorson E & 58.776 & McCroskey JC & 68.276 \\
\hline 11 & Potter WJ & 57.551 & Signorielli N & 68.276 \\
\hline 12 & Perse EM & 57.143 & Berger CR & 67.586 \\
\hline 13 & Allen M & 56.735 & Bryant J & 67.586 \\
\hline 14 & Sundar SS & 56.735 & Gunter B & 66.897 \\
\hline 15 & Johnson JD & 56.327 & Eveland WP & 66.207 \\
\hline 16 & Newhagen JE & 56.327 & Brosius HB & 64.828 \\
\hline 17 & Brashers DE & 55.918 & Atkin CK & 63.448 \\
\hline 18 & Signorielli N & 55.918 & Scheufele DA & 63.448 \\
\hline 19 & Austin EW & 55.51 & Austin EW & 62.759 \\
\hline 20 & Johnson TJ & 55.51 & Dunwoody S & 61.379 \\
\hline 21 & McCombs M & 55.51 & Meyrowitz J & 60.69 \\
\hline 22 & Shah DV & 55.51 & Salmon CT & 60.69 \\
\hline 23 & Eveland WP & 55.102 & Newhagen JE & 59.31 \\
\hline 24 & Perloff RM & 55.102 & Slater MD & 59.31 \\
\hline 25 & Shanahan J & 55.102 & Benoit WL & 58.621 \\
\hline 26 & Morgan M & 54.694 & Graber D & 58.621 \\
\hline 27 & Walther JB & 54.694 & McCombs M & 58.621 \\
\hline 28 & McLeod JM & 53.878 & Moy P & 58.621 \\
\hline 29 & Neuman WR & 53.878 & Walther JB & 58.621 \\
\hline 30 & Anderson JA & 53.469 & Ettema JS & 57.931 \\
\hline
\end{tabular}

\section{Restrictions and Further Research}

In spite of the usefulness as a research tool as well as its original purpose of offering bibliographic information, there are some restrictions when using the Web of Science database for data collection. In the "cited reference" search, the first step shows a list of cited references for the searched author. The second step shows a list of citing articles for the selected references in step 1. However, even the "select all" function lets the user to choose only 
the first 500 references, rather than the whole set of cited references. Although there are not many authors who have more than 500 works that are cited by others, it still limits the comprehensiveness of the data. It offers an option for sorting the results by publication date, times cited, relevance, first author's last name, and source title, but it still requires judgment of the researcher that may lead to bias. Secondly, the data used for this study requires tedious and lengthy process of data collection by performing the same searches repeatedly. The advanced search option exists, but it still prevents users from many functions, such as simultaneous multiple searches. It also offers to save the search history, but only up to 40 sets. Due to these restrictions in data collection, the search results may or may not include the complete set of citing articles under investigation. Although the cocitation method reduces such errors, if the search yields the accurate set of citing articles in the first place, the errors should not be an issue. Some researchers developed their own method of collecting citation indexing data (Kim and Kim 2007) and added other analysis methods such as multivariate analysis, cluster analysis, and factor analysis for more accurate result.

On the other hand, one of the advantages of the research lies in its expandability. The original plan for the research included the editorial boards of other ICA published journals, such as Human Communication Research and Communication Theory. It must have been interesting to compare the results for the editorial boards of each journal and to see how each journal has different structure. It can also apply to other group of scholars, journals or documents, and include other attributes that may affect the structure of the cocitation network. Likewise, there are other studies using editorial boards of journals in various subject fields (Baccini and Barabesi 2011; Burgess and Shaw 2010; Malin and Carley 2007). Even if it is not about clusters and attributes, it may be useful to see if the network structure changes depending on the chief editor. It can also extend to a co-authorship network, as in Moody (2004), and examine the structural cohesion of the network (Moody and White 2003) or explore the structural holes of a network (Rosen 2009; Kalish and Robbins 2006). Chon and Han (2007) used author cocitation analysis for examining separate citation networks of citing authors and cited authors. For networks of citing authors, social capital and common research topic can influence the creation of a cluster. For cited authors, 5 main clusters were identified, especially focusing on subjects such as (1) culture / gender, (2) broadcasting / new media / interaction, (3) media ethics legislation, and (4) broadcasting and new media policy. In addition, the study can also apply other attributes. For instance, the age of scholars can be a factor that can affect patterns of citation (Barnett and Fink 2008, 528; Kim and Cho 2010; Ryoo and Choi 2011). In conclusion, the study tried to examine whether the pattern of author cocitation can be used as a predictor for the structure of the communication field, and especially, the implication of the existence of invisible colleges in a subject specialty. As the networked map of authors showed, the structure of cocitation network appears to be similar to what the subfields 
of the communication research. The scholars are clustered into groups of mass communication, organizational communication, interpersonal communication, and so on. Replications of this study will be able to investigate the structure of knowledge in other areas of research.

\section{References}

김영준, 김채환. 2007. “국내언론학의 지적구조매핑 (mapping)에 관한 연구: 1989 2006년 저자 동시인용분석.『커뮤니케이션학연구』, 15(3): 155-183.

김용학, 김영진, 김영석. 2008. "한국 언론학 분야 지식 생산과 확산의 구조》 『한국언론학보』, 52(1): 117-140.

김희전, 조현양. 2010. “저자동시인용분석과 저자서지 결합분석에 의한 지적구조분석: 사회복지학 분야를 중심으로”『정보관리학회지』, 27(3): 283-306.

유종덕, 최은주. 2011. "저자프로파일링분석과 저자동 시인용분석의 유용성 비교검증." 『정보관리 학회지』, 28(1): 123-144.

전범수, 한상권. 2007. "한국 언론학 연구의 지식생산 연결망구조."『한국언론학보』, 51(6): 197215.

Baccini, Alberto and Lucio Barabesi. 2011. "Seats at the table: The network of the editorial boards in information and library science." Journal of Informatics, 5(3): 382-391.

Barnett, G.A. 2001. "A longitudinal analysis of the international telecommunication network, 1978-1996." American Behavioral Scientist, 44: 1638-1655.
Barnett, G.A. and Y. Choi. 1995. "Physical distance and language as determinants of the international telecommunications network." International Political Science Review, 16: 249265.

Barnett, G.A. and J. A. Danowski. 1992. "The structure of communication: A network analysis of the International Communication Association." Human Communication Research, 19(2): 264-285.

Barnett, G.A. and E. L. Fink. 2008. "Impact of the Internet and scholar age distribution on academic citation age." Journal of the American Society for Information Science and Technology, 59(4): 526-534.

Barnett, G. A. and H.W. Park. 2005. "The structure of international Internet hyperlinks and bilateral bandwidth." Annales des te'le'communications, 60(9-10): 1110-1127.

Barnett, G.A. and J.G.T. Salisbury. 1996. “Communication and globalization: A longitudinal analysis of the international telecommunication network." Journal of World System Research, 2(16): 1-17.

Barnett, G.A., J.G.T. Salisbury, C. Kim, and A. 
Langhorne. 1999. "Globalization and international communication: An examination of monetary, telecommunications, and trade networks." Journal of International Communication, 6(2): 7-49.

Borgatti, S.P. 2005. "Centrality and network flow." Social Networks, 27: 55-71.

Brown, J.S. and P. Duguid. 1998. "Organizing knowledge." California Management Review, 40(1): 90-111.

Burgess, Thomas F. and Nicola E. Shaw. 2010. "Editorial board membership of management and business journals: A social network analysis study of the Financial Times 40." British Journal of Management, 21(3): 627648.

Chang, T. and Z. Tai. 2005. "Mass communication research and the invisible college revisited: The changing landscape and emerging fronts in journalism-related studies." Journalism and Mass Communication Quarterly, 82(3): 672-694.

Crane, D. 1972. Invisible Colleges: Diffusion of Knowledge in Scientific Communities. Chicago and London: The University of Chicago Press.

Cronin, B. 1984. The Citation Process: The Role and Significance of Citations in Scientific Communication. London: Taylor Graham.

Freeman, L.C. 1978/1979. "Centrality in social networks: Conceptual clarification.” Social Networks, 1: 215-239.

Freudenthal, G. 1984. "The role of shared knowledge in science: The failure of the constructivist programme in the sociology of science." Social Studies of Science, 14: 285-295.

Fuchs, S. 1993. "A sociological theory of scientific change.” Social Forces, 71(4, June): 933-953.

Garfield, E. 1965. "Can citation indexing be automated?" In Stevens M.E., V.E. Giuliano, and L.B. Heilprin (Eds.), Statistical Association Methods for Mechanized Documentation: Symposium Proceedings, 189-192, Washington, DC: National Bureau of Statistics.

Garfield, E. 2004. "The unintended and unanticipated consequences of Robert K. Merton.” Social Studies of Science, 34(6, December): 845-853.

Granovetter, M.S. 1973. "The strength of weak ties." American Journal of Sociology, 78(6, May): 1360-1380.

Griffith, B.C. 1989. "Understanding science: Studies of communication and information." Communication Research, 16(5): 600-614.

Griffith, B.C. and N. C. Mullins. 1972. "Coherent social groups in scientific change." Science, New Series, 177(4053, September): 959-964.

Haythornthwaite, C. 2002. "Strong, weak, and latent ties and the impact of new media." Information Society, 18(5): 385-401.

Hess, D.J. 1997. Science Studies: An Advanced Introduction. New York and London: New York University Press.

Kalish, Y. and G. Robins. 2006. "Psychological predispositions and network structure: The relationship between individual predispositions, structural holes and network closure." Social Networks, 28: 56-84. 
Koku, E., N. Nazer, and B. Wellman. 2001. 'Netting scholars." American Behavioral Scientist, 44(10, June): 1752-1774.

Kuhn, T.S. 1962. The Structure of Scientific Revolutions, International Encyclopedia of Unified Science. Vol.2, No.2. Chicago: The University of Chicago Press.

Kuhn, T.S. 1996. The Structure of Scientific Revolutions ( $3^{\text {rd }}$ ed.). Chicago: University of Chicago Press.

Lee, S. 2008. Understanding the Nature of Citation: An Examination of Structure in Citation Analysis and itsApplication to Communication in the Information Age. Ph.D. Diss., State University of New York at Buffalo.

Lievrouw, L.A. 1989. "The invisible college reconsidered: Bibliometrics and the development scientific communication theory." Communication Research, 16(5, October): 615-628.

Malin, Bradley and Kathleen Carley. 2007. "A longitudinal social network analysis of the editorial boards of medical informatics and bioinformatics journals." Journal of the American Medical Informatics Association, 14(3): 340348.

Marion, L.S. 2002. "A tri-citation analysis exploring the citation image of Kurt Lewin.” Proceedings of the ASIST Annual Meeting, 39: 3-13.

Marion, L.S., E. Garfield, L.L. Hargens, L.A. Lievrouw, H.D. White, and C.S. Wilson. 2003. "Social network analysis and citation network analysis: Complementary approaches to the study of scientific communication."
Proceedings of the American Society for Information Science and Technology, 40(1): 486-487.

McCain, K.W. 1986. "Cocited author mapping as a valid representation of intellectual structure." Journal of the American Society for Information Science, 37(3): 111-122.

McCain, K.W. 1989. "Mapping authors in intellectual space: Population genetics in the 1980s." Communication Research, 16(5, October): 667-681.

McCain, K.W. 2009. "Using tricitation to dissect the citation image: Conrad Hal Waddington and the rise of evolutionary developmental biology." Journal of the American Society for Information Science and Technology, 60(7): 1301-1319.

Merton, R.K. 1942. "Science and technology in a democratic order." Journal of Legal and Political Sociology, 1: 115-126.

Merton, R.K. 1996. "Multiple discoveries in science." In P. Sztompka (Ed.). On Social Structure and Science, 305-317. Chicago and London: The University of Chicago Press.

Monge, P.R. and N.S. Contractor. 2003. Theories of Communication Networks. Oxford and New York: Oxford University Press.

Moody, J. 2004. "The structure of a social science collaboration network: Disciplinary cohesion from 1963 to 1999." American Sociological Review, 69(April): 213-238.

Moody, J. and D.R. White. 2003. "Structural cohesion and embeddedness: A hierarchical con- 
cept of social groups." American Sociological Review, 68(February): 103-127.

Paisley, W. 1972. "The role of invisible colleges in scientific information transfer." Educational Researcher, 1(4, April): 5-8+19.

Park, H.W. and Loet Leydesdorff. 2009. "Knowledge linkage structures in communication studies using citation analysis among communication journals." Scientometrics, 81(1): 157175.

Popper, K. 1959. The Logic of Scientific Discovery. New York: Basic Books, Inc.

Popper, K. 1965. Conjectures and Refutations: The Growth of Scientific Knowledge. New York: Basic Books, Inc.

Price, D.J. de Solla. 1961. Science since Babylon. New Haven: Yale University Press.

Price, D.J. de Solla. 1963. Little Science, Big Science. New York: Columbia University Press.

Price, D.J. de Solla and D. Beaver. 1966. "Collaboration in an invisible college." American Psychologist, 21(11): 1011-1018.

Rice, R.E., C.L. Borgman., and B. Reeves. 1988. "Citation networks of communication journals, 1977-1985: Cliques and positions, citations made and citations received." Human Communication Research, 15(2): 256-283.

Rosen, D. 2009. "Productivity and performance in academic networks: Applications of liaison communication to Simmelian ties, structural holes, and degree centrality." Connections, 29(2): 32-43.

Small, H. 1973. "Co-citation in the scientific liter- ature: A new measure of the relationship between two documents." Journal of the American Society for Information Science, 24(4): 265-269.

Small, H. 1977. "A co-citation model of a scientific specialty: A longitudinal study of collagen research." Social Studies of Science, Theme Issue: Citation Studies of Scientific Specialties, 7(2): 139-166.

Tankard, J.W. Jr., T. Chang, and K. Tsang. 1984. "Citation networks as indicators of journalism research activity.” Journalism Quarterly, 61(Spring): 89-96.

Tsuzuki, K. 2005. "Some conceptual problems of social capital: Tie, strength of tie and trust." Sociological Theory and Methods, 20(1): 81-95.

Wasserman, S. and K. Faust. 1994. Social Network Analysis: Methods and Applications. Cambridge: Cambridge University Press.

White, H.D. 1981. "Cocited author retrieval online: An experiment with the social indicators literature." Journal of the American Society for Information Science, 32(1): 16-21.

White, H.D. 2003. "Author cocitation analysis and Pearson's r." Journal of the American Society for Information Science and Technology, 54(13): 1250-1259.

White, H.D. 2004. "Citation analysis and discourse analysis revisited." Applied Linguistics, 25(1): 89-116.

White, H.D. and B.C. Griffith. 1981. "Author cocitation: A literature measure of intellectual 
structure." Journal of the American Society for Information Science, 32(3): 163-171.

White, H.D. and K.W. McCain. 1989. "Bibliometrics." Annual Review of Information Science and Technology, 24: 119-186.

White, H.D. and K.W. McCain. 1998. "Visualizing a discipline: An author co-citation analysis of information science, 1972-1995." Journal of the American Society for Information Science, 49(4): 327-355.

White, H.D., B. Wellman, and N. Nazer. 2003. 'Does citation reflect social structure?: Longitudi- nal evidence from the "Globenet" interdisciplinary research group." Journal of the American Society for Information Science and Tehcnology, 55(2): 111-126.

Yakubovich, V. 2005. "Weak ties, information, and influence: How workers find jobs in a local Russian labor market." American Sociological Review, 70(3): 408-421.

Zuccala, A. 2004. "Modeling the invisible college." Journal of the American Society for Information Science and Technology, 57(2): 152168. 